\title{
ADSORPTION OF GLYCINE ON AMORPHOUS CALCIUM PHOSPHATE AND ITS THERMAL STABILITY
}

\author{
Yoshiyuki KOJIMA, Yoshinari YAMAMOTO, Tamotsu YASUE and Yasuo ARAI \\ Department of Industrial Chemistry, Faculty of Science and Engineering, \\ Nihon University, 1-8, Kanda-Surugadai, Chiyoda-ku, Tokyo 101, Japan
}

\begin{abstract}
Adsorption of glycine on amorphous calcium phosphate and its thermal stability were investigated by the reactions in an aqueous solution of $\mathrm{CaCl}_{2}-\mathrm{K}_{2} \mathrm{HPO}_{4}-\mathrm{C}_{2} \mathrm{H}_{5} \mathrm{O}_{2} \mathrm{~N}-\mathrm{KOH}$ system. Characterization of the products was determined by means of X-ray diffraction, thermal analysis (TG-DTA), infrared absorption spectrometry and ion chromatography. The largest quantity of glycine adsorbed on amorphous calcium phosphate having $\mathrm{Ca} / \mathrm{P}$ atomic ratio of 1.65 was $8.5 \mathrm{mass} \%$ when it is synthesized under the conditions of temperature at $0{ }^{\circ} \mathrm{C}$, initial pH 10.0 and $\mathrm{C}_{2} \mathrm{H}_{5} \mathrm{O}_{2} \mathrm{~N} / \mathrm{CaCl}_{2}$ molar ratio 11.0 , and then aged at $40^{\circ} \mathrm{C}$. It was proved that the glycine as one of the amino acids was more tightly adsorbed on the surface of amorphous calcium phosphate than on HAp. The glycine adsorbed on amorphous calcium phosphate was started decomposition at above $200{ }^{\circ} \mathrm{C}$, was finished at $600^{\circ} \mathrm{C}$, and amorphous calcium phosphate was then transformed to $\alpha$-type tricalcium phosphate at around $660^{\circ} \mathrm{C}$.
\end{abstract}

\section{INTRODUCTION}

The ceramic materials related to a living body have been recently attracting attention as bioactivematerials which directly bond with hard tissues in vivo. The major component of hard tissues in vivo is known as hydroxyapatite $\left(\mathrm{Ca}_{10}\left(\mathrm{PO}_{4}\right)_{6}(\mathrm{OH})_{2}, \mathrm{HAp}\right)$. It was accepted that amorphous calcium phosphate (ACP) was generally formed during the initial stage of HAp synthesis and was eventually transformed to low crystalline $\mathrm{HAp}^{1)}$. The formation of bone in vivo is considered such that calcium phosphate obtained during formation stage of ACP to crystal growth process of HAp was forming layer complex by regularly lining to periphery collagen, a fibrous protein. The collagen constituting from three kinds of protein, glycine, proline and alanine, had function coating to calcium salts by filling in gap of cell or forming insolubility frame group ${ }^{2)}$. The glycine was existed about $35 \%$ in amino acid constituting collagen and make up basis of collagen.

Further, the glycine was formed from amino acid taken into a living body from

Received October 17, 1995; Accepted December 11, 1995 
the outside. It was then synthesized by the glyolysis process after undergoing the tricarboxylic acid (TCA) cycle to be transformed into various organic acid, such as malic and succinic acids, as the intermediates ${ }^{3)}$. Many researches have been discussing crystalline calcium phosphates, particularly HAp interactions with organic compounds, collagen and gelatin as the protein ${ }^{4) \sim 11)}$. The authors have been already investigated $\mathrm{ACP}$-succinic acid composites precipitated by aqueous solution reaction of $\mathrm{CaCl}_{2}-\left(\mathrm{NH}_{4}\right)_{2} \mathrm{HPO}_{4}-\mathrm{C}_{4} \mathrm{H}_{6} \mathrm{O}_{4}-\mathrm{NH}_{4} \mathrm{OH}$ system. As a result, the largest quantity of succinic acid could be most effectively adsorbed on ACP when it was synthesized under the conditions of temperature at $0^{\circ} \mathrm{C}$ and initial $\mathrm{pH} 10.0$ to have 6.0 mass $\%$ of the acid, then aged at 0 to $40^{\circ} \mathrm{C}^{12)}$. In this study, amount of glycine adsorbed on ACP and its thermal stability in order to understand the basic aspects on ACP-protein composites were investigated.

\section{EXPERIMENTAL}

\section{MATERIALS}

The reagents used for the synthesis of ACP adsorbing glycine were anhydrous calcium chloride $\left(\mathrm{CaCl}_{2}\right)$, dipotassium hydrogenphosphate $\left(\mathrm{K}_{2} \mathrm{HPO}_{4}\right)$, potassium hydroxide $(\mathrm{KOH})$ and glycine $\left(\mathrm{C}_{2} \mathrm{H}_{5} \mathrm{O}_{2} \mathrm{~N}\right)$ as amino acid, all supplied by Kanto Chemical Co.,Ltd. In addition, reagent grade HAp (100 to 200 meshes) for column chromatography supplied by Nakaraitesuku Co., Ltd. was also used for comparison.

\section{EXPERIMENTAL METHOD}

ACP which adsorbed glycine was synthesized by rapidly adding $\mathrm{CaCl}_{2}$ solution $\left(0.167 \mathrm{~mol} \mathrm{dm}^{-3}\right)$ into $\mathrm{K}_{2} \mathrm{HPO}_{4}$ solution $\left(0.100 \mathrm{~mol} \mathrm{dm}^{-3}\right)$. In advance, the $\mathrm{K}_{2} \mathrm{HPO}_{4}$ solution was added with powdered glycine $(0 \sim 1.94 \mathrm{~mol})$ and with the KOH solution to control $\mathrm{pH}$ during the synthesis process. Volume of the $\mathrm{CaCl}_{2}$ solution was set to the same as that of the $\mathrm{K}_{2} \mathrm{HPO}_{4}$ solution, and reaction temperature was controlled at $0{ }^{\circ} \mathrm{C}$. Gelatinous ACP which adsorbed glycine was formed immediately after the reaction, was aged in the mother liquor at $0 \sim 40^{\circ} \mathrm{C}$ for $0 \sim 24 \mathrm{~h}$, and was then filtered by a glass filter(G5). The gel was washed with KOH kept at the same $\mathrm{pH}$ as that used for the synthesis and acetone, treated with silica gel to remove moisture and finally dried in air to prepare ACP which adsorbed glycine. The characterization of the products were determined by means of X-ray diffraction, thermal analysis(TG-DTA), infrared adsorption spectrometry and ion chromatography. The product compositions were determined quantity of calcium by 
chemical analysis, and quantities of phosphorus and glycine adsorbed on the products by ion chromatography (column: Toa Denpa Kogyo Co.Ltd.,PCI-305s and PCI-302s).

\section{RESULTS AND DISCUSSION}

\section{ADSORPTION OF GLYCINE ON AMORPHOUS CALCIUM PHOSPHATE}

The authors have already discussed that the ACP (Ca/P atomic ratio: 1.65) having a composition near to the theoretical HAp composition ( $\mathrm{Ca} / \mathrm{P}$ atomic ratio: 1.67) could been be synthesized at an initial $\mathrm{pH}$ level of 10.0 . And then, $\mathrm{Ca} / \mathrm{P}$ atomic ratio of ACP formed in the presence of glycine was almost independent of glycine concentration. ACP formed was kept in the mother liquor in order to investigate on amount of glycine adsorbed on its surface.

ACP remained amorphous during the initial aging stage at up to $5 \mathrm{~h}$ under the conditions of $\mathrm{C}_{2} \mathrm{H}_{5} \mathrm{O}_{2} \mathrm{~N} / \mathrm{CaCl}_{2}$ molar ratio 11.0 , initial $\mathrm{pH} 10.0$ and aging temperature at $25^{\circ} \mathrm{C}$, shown broad patterns characteristic of amorphous state.

It was thus confirmed that glycine works to retard the crystallization, keeping amorphous state for $5 \mathrm{~h}$ during the aging process, which was then crystallized into low crystalline HAp. ACP was crystallized faster in the absence of glycine because glycine was adsorbed on surface of ACP. Amount of glycine adsorbed was affected some conditions such as glycine concentration in the mother liquor, initial $\mathrm{pH}$ and aging temperature.

Figure 1 illustrates the effects of glycine concentration and aging time on the quantity of glycine adsorbed on ACP synthesized under the conditions of initial $\mathrm{pH} 10.0$ and aging temperature at $25^{\circ} \mathrm{C}$. The quantity of glycine adsorbed on ACP tended to increase as glycine concentration was increased. The quantity attained a maximum at an aging time of $5 \mathrm{~h}$, irrespective of glycine concentration, exhibiting the highest level of 8 mass\% at $\mathrm{C}_{2} \mathrm{H}_{5} \mathrm{O}_{2} \mathrm{~N} / \mathrm{CaCl}_{2}$

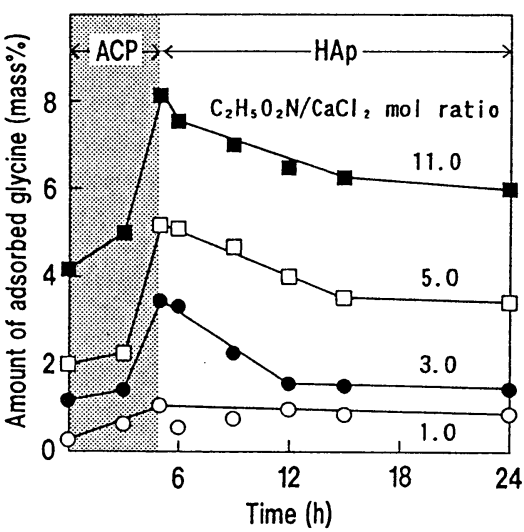

FIGURE 1 Effect of glycine concentration on amount of adsorbed glycine on amorphous calcium phosphate.

Initial pH:10.0, Aging temperature: $25^{\circ} \mathrm{C}$ molar ratio 11.0 . It decreased with time 
after 5 h, conceivably resulting from progress of crystallization of ACP to HAp. The quantity of organic substance adsorbing on ACP under same the conditions was slightly higher glycine than adsorption dissolved succinic acid in previous a report, because glycine was hydrophilic amino acid and was increased solubility in water compare with succinic acid. The stability in mother liquor of ACP was tended to extend as initial $\mathrm{pH}$ was increased. In this study, initial $\mathrm{pH}$ was controlled 10 .

Figure 2 illustrates the effects of aging temperature on adsorption of glycine on ACP. Under low aging temperature of $0^{\circ} \mathrm{C}$, amount of glycine adsorbed on ACP was even approximately 6 mass\% at aging time for 24h. This result was retarded crystallization from ACP to HAp compare with aging at room temperature and was to be stability. However, adsorption rate of glycine was accelerated according to raising temperature. The quantity adsorbed was exhibited the highest level of 8.5 mass\% under the conditions of $40^{\circ} \mathrm{C}$ for $1 \mathrm{~h}$. When regent HAp was dipped into glycine solution, glycine adsorbed was slight quantity.

CHARACTERIZATION OF AMORPHOUS CALCIUM PHOSPHATE ADSORBED GLYCINE

Figure 3 illustrates infrared adsorption spectrum of ACP adsorbed glycine. ACP which adsorbed glycine (c) had adsorption spectra at around $1610 \mathrm{~cm}^{-1}$ and $1420 \mathrm{~cm}^{-1}$, which were assigned to -COOCa- group ${ }^{13), 14)}$, but these spectra was not observed to glycine (a) or mixture glycine and ACP (b). These spectra were also observed with the sample thoroughly washed with the $\mathrm{KOH}$ solution with the

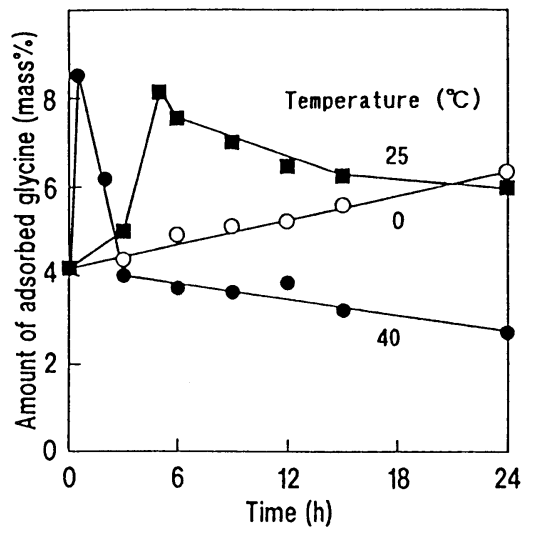

FIGURE 2 Effect of aging temperature on amount of adsorbed glycine on amorphous calcium phosphate. Initial pH: $10.0, \mathrm{C}_{2} \mathrm{H}_{5} \mathrm{O}_{2} \mathrm{~N} / \mathrm{CaCl}_{2}$ molar ratio: 11.0

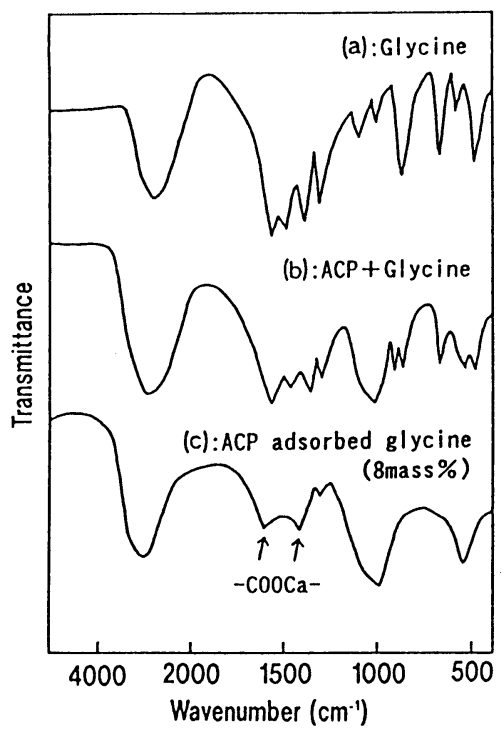

FIGURE 3 Infrared spectra of amorphous calcium phosphate with adsorbed glycine and raw sample. 
adjusted $\mathrm{pH}$ for the synthesis, indicating that glycine was strongly adsorbed on ACP.

Figure 4 (A) is the TG-DTA curve of ACP synthesized under the conditions of aging temperature at $25^{\circ} \mathrm{C}$ and initial $\mathrm{pH} 10.0$, where ACP adsorbs glycine of 8.0 mass\%. Figure 4 (B) present the X-ray diffraction patterns at temperature of (a) through (d), shown in Fig.4(A). There were two types of water molecules present in ACP, adsorbed water and bound water ${ }^{15)}$. Therefore, the endothermic peak formed in the DTA curve at around $100{ }^{\circ} \mathrm{C}$ resulted from dehydration of bound water. The exothermic peak found at $320^{\circ} \mathrm{C}$ was due to combustion by decomposed carboxyl group of glycine adsorbed on ACP. However, the decomposition of glycine adsorbed found wide region of 200 and $600{ }^{\circ} \mathrm{C}$.

There was a shape exothermic peak at around $660{ }^{\circ} \mathrm{C}$. The $\mathrm{X}$-ray diffraction patterns (B) indicated that the sample heated up to $600{ }^{\circ} \mathrm{C}$

(b) had the characteristic broad patterns
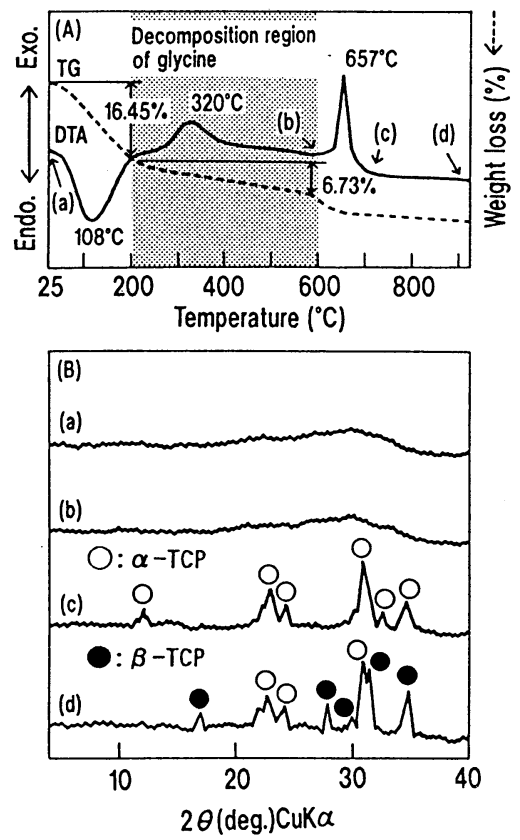

FIGURE 4 Thermal decomposition process of amorphous calcium phosphate with adsorbed glycine.

(A) TG-DTA curve,

(B) X-ray diffraction patters of amorphous substance, however, the one heated to $700{ }^{\circ} \mathrm{C}(\mathrm{d})$ had the peaks relevant to $\alpha$-type tricalcium phosphate $\left(\mathrm{Ca}_{3}\left(\mathrm{PO}_{4}\right)_{2}, \alpha-\mathrm{TCP}\right)$. Namely, the exothermic peak at around $660^{\circ} \mathrm{C}$ was due to crystallization of ACP to TCP. Further, TCP could divide into $\beta$-phase of low temperature type and $\alpha$-phase of high temperature type ${ }^{16)}$. It was confirmed that $\alpha$-phase of semi-stability due to heat amorphous substance was first formed at low temperature ${ }^{17)}$.

Above the results, adsorption of glycine on ACP was remained at up to around $660^{\circ} \mathrm{C}$, but the stability of the product was effective below $200{ }^{\circ} \mathrm{C}$ without decomposition of glycine.

\section{REFERENCE}

1) T.Yasue and Y.Arai, Sekko to Sekkai, No.243,42(1993).

2) Y.Kondo, "Davies Littlewood / Elementary Biochemistry",

Tokyo-Kagaku-Dojin, (1986)p.13. 
3) H.Ishikura,K.Kasai, I. Shibuya and T.Yagi, "Illustration for biochemical" , Maruzen, (1986)p. 56.

4) T.Horiguchi, Y.Doi , S.Kim, N.Wakamatsu, M.Adachi, S. Imura, K.Hayashi and T.Gyotoku, Shika-Zairyo - Kikai, Vol.9, No.6, 863(1990).

5) T.Horiguchi, Y.Doi, S.Kim, N.Wakamatsu, M.Adachi, S. Imura, K. Hayashi and T.Gyotoku, Shika-Zairyo - Kikai, Vol.10, No.6,814(1991).

6) S.Matsushita, I.Motooka and Y.Kanaji, J.Chem.Soc.Jpn., No.5, 409(1994).

7) T.Horiguchi and Y.Doi, S.Kim, "Proceedings of the First International Symposium on Apatite", Mishima, Japan July (1991)p.175.

8) K.S.TenHuisen and P.W.Brown, J.Biochem.Mater.Res. , 28, 27(1994).

9) N.Sasaki, H.Umeda, S.Okada, R.Kojima and A.Fukuda, Biomaterials, 10, 129(1989).

10) S.S.Schwartz,D.I.Hay and S.K.Schluckebier, Calcif Tissue Int., 50,511(1992).

11) G.M.McCarthy,P.G.Mitchell, J.A.Struve and H.S.Cheung, J.Cellular Phys., $153,140(1992)$.

12) T.Yasue, K.Masuda, Y.Kojima and Y.Arai, J.Ceram.Soc.Jpn., 102, 1122(1994).

13) H.Monma, Sekko to Sekkai, No.237,38(1992).

14) M.Tsuboi and T.Takenishi, Infrared Spectrum-Area of Chemistry-Publish, No. 37, 43(1959).

15) Y.Kojima, K. Sakama, T.Toyama, T. Yasue and Y.Arai, Phosph.Res.Bull . , 4, 47(1994).

16) H.Monma and M.Goto, Yogyo-Kyokai-Shi , 91, 55(1983).

17) T.Kanazawa, T.Umegaki and N.Uchiyama, J.Chem.Tech.Biotechnol., 32, 399(1982). 